\title{
The use of graphs as an impression management tool in the annual integrated reports of South African listed entities
}



Orientation: The annual integrated report is one of the primary means used by companies to communicate with stakeholders regarding both financial and non-financial information. However, the format of the annual integrated report has changed, resulting in different communication mediums being used. Graphic disclosure is being used more widely for both financial and non-financial information. Although beneficial, graphs may also be used by management to manipulate how readers interpret results.

Research purpose: The purpose of the study was to analyse the frequency, quality and measurement distortion of graphs in the annual reports of the top 100 South African listed companies.

Motivation for the study: Research on graph usage in South Africa is limited. The study explored the extent to which South African listed companies use graphs in annual reports and if graphs are employed as an impression management tool.

Research approach/design and method: The study followed a descriptive quantitative research method. Graphs in the annual reports of the sampled companies were analysed based on guidelines developed by earlier researchers to determine the quality and measurement distortion of graphs.

Main findings: Graphs are used widely by South African listed companies. South African companies do not enhance the presentational features of graphs to a large degree, but the graphs analysed show significant measurement distortion. Graphs presented tended to overstate the underlying trend as opposed to an understatement.

Practical/managerial implications: The study will be beneficial to the users, regulatory bodies, auditors and the management of companies to understand how graphs can be used to alter the presentation of results, which could result in incorrect decisions being taken.

Contribution/value-add: This study contributes to the body of research regarding the quality of annual integrated reports in a South African context and may assist users who use these reports to understand how graphs can be used as a manipulation tool.

Keywords: annual integrated report; graph; impression management; measurement distortion; presentational enhancement.

\section{Introduction}

\section{Orientation}

Traditional financial reporting, which is retrospective, focuses only on a portion of the company's status and does not provide a holistic view (Bernardi \& Stark 2016; Surty, Yasseen \& Padia 2018; Türker \& Zafer 2014). Integrated reporting presents the opportunity to establish the link between the financial, social and environmental information of organisations (Reuter \& Messner 2015; Roberts 2014).

The increase in information has resulted in an increase in the volume and complexity of information presented in company reports, resulting in users finding it difficult to read annual integrated reports (Frownfelter-Lohrke \& Fulkerson 2001; Rezaee \& Porter 1993). In an attempt to simplify reporting, narratives are being used more frequently as it allows for easier understanding (Rentz 1992; Rogers \& Grant 1997). Graphs are a form of narrative information, which may be considered valuable as graphs focus the readers' attention as they summarise information, 
highlight trends and also explain complicated relationships (Beattie \& Jones 2008a; Frownfelter-Lohrke \& Fulkerson 2001). Whilst there has been an increase in the use of graphs, no guidelines are provided on the presentation of graphs in annual integrated reports, although there have been recommendations (Mather, Mather \& Ramsay 2005). As a result, the use of graphs, although advantageous, is not problem-free, as it could be a means by which management manipulates the information disclosed to create a better impression for the reader (Beattie \& Jones 1999, 2008a).

\section{Research purpose and objectives}

This study specifically aimed to determine whether graphs used by South African companies have elements of impression management and will, ultimately, result in reporting bias. In order to achieve this, the annual integrated reports of the top 100 companies listed on the Johannesburg Stock Exchange (JSE) were analysed using the following four research questions, which have been replicated based on the study by Frownfelter-Lohrke and Fulkerson (2001):

RQ1: What is the frequency of graphs included in the annual integrated reports of the top 100 South African listed companies?

RQ2: What is the subject matter of graphs included in the annual integrated reports of the top 100 South African listed companies?

RQ3: Do the graphs included in the annual integrated reports of the top 100 South African listed companies comply with standards for good graphs?

RQ4: Are the graphs presented in the annual integrated reports of the top 100 South African listed companies distorted (measured using the graph discrepancy index)?

The study relating to graphs would be beneficial to the users of annual integrated reports, regulatory bodies, auditors and the management of companies. The results will provide insight into the use of graphs as impression management tools and how users can respond. For instance, users will be able to understand how graphs can manipulate perceptions, auditors can adapt audit procedures for such manipulations and management can ensure that there is proper oversight over the annual integrated report, allowing the report to represent the results of a company truthfully (De Klerk \& Van Wyk 2017). It is important to note that, given the accounting scandals both globally and locally, the results of companies are accurate to facilitate appropriate decisionmaking (Yasseen, Moola-Yasseen \& Padia 2017).

The article is structured as follows: The following section provides a literature review, followed by the research methodology. Thereafter, the results and conclusions of the study, limitations and areas of future research will be discussed.

\section{Literature review}

In order to provide insights into the use of graphs within a South African context, a structured literature review method was adopted. A structured literature review is a method for studying a body of scholarly literature to develop insights, critical reflections, future research paths and research questions (Massaro, Dumay \& Guthrie 2016). A structured literature review has been used in similar studies by Engelbrecht, Yasseen and Omarjee (2018) and Yasseen et al. (2017).

The literature review is structured as follows: 'Importance of the annual integrated report' discusses the importance of the annual integrated report, including the change in reporting over time; 'Use of graphs' discusses the reasons for the use of graphs; 'Impression management and the use of graphs' explains how graphs can be used as a tool of impression management; 'Guidelines which can be considered for good graph design' discusses the guidelines for good graphs; 'Calculation of measurement distortion' discusses how measurement distortion is calculated, and 'Results of graph use from other studies' provides an overview of the results from prior studies regarding the use of graphs.

\section{Importance of the annual integrated report}

The annual integrated report is a formal public document produced by public companies as a response to the mandatory corporate reporting requirements of most economies (Stanton \& Stanton 2002). Users of the annual integrated report include employees, customers, suppliers, business partners, local communities, legislators, regulators and policymakers (IIRC 2013).

Although there are various modes of communication, the annual integrated report is considered to be an important means of communication between companies, investors and the broader financial community (Chang \& Most 1985; Frownfelter-Lohrke \& Fulkerson 2001; Lee \& Tweedie 1975a). The annual integrated report is viewed as an influential source of information as it is widely circulated and information is easily accessible in one document (Hooks, Coy \& Davey 2002; Marston \& Shrives 1991; Stanga 1976).

The annual integrated report is divided into two sections, namely the narrative section and the financial section (Stanton \& Stanton 2002; Uyar 2009). The narrative section is usually subject to little oversight: the information is unaudited and voluntary; the financial section, on the other hand, is strongly regulated, mandatory and audited (Beattie \& Jones 2000b; Penrose 2008).

There is no rule that the annual financial statements must be included as part of the integrated report and the companies are offered flexibility (Roberts 2014). In South Africa, there are companies that choose to produce one report, with the integrated report included as the narrative section and the annual financial statements follow - the so-called 'annual integrated report' (Bray \& Chapman 2012; Roberts 2014). In other cases, the abridged financial statements are included with the integrated report, with the full annual statements available in a separate document (Roberts 2014). For the purposes of this study, the annual integrated report was used 
where such a report was published, and if not, the integrated report was used.

\section{Change in reporting landscape - South Africa and abroad}

South Africa led the way in the formalisation of integrated reporting as it was the first country to take on the implementation of integrated reporting (Elda, Renier \& Gina 2017). With effect from March 2010, the JSE required all listed companies to comply with the recommendations of King III (Atkins \& Maroun 2015). In November 2016, the King IV Report on Corporate Governance (King IV) was released with an effective date of 1 April 2017 (EY 2018).

Integrated reporting is the communication to stakeholders regarding how a company's strategy, governance and prospects lead to the creation of value over time and relays a company's journey in a clear manner (IIRC 2013; IRCofSA 2014). Integrated reporting not only focuses on financial reporting or sustainability reporting but connects the financial and non-financial information (IRCofSA 2014). King IV considers the change in the reporting landscape in terms of the shift to more holistic reporting and the creation of sustainable value (IoDSA 2016). As such, integrated thinking, which considers that a range of factors may impact an organisation, is an underpinning philosophy in King IV (IoDSA 2016). Furthermore, the drafting of King IV considered the International Framework issued by the International Integrated Reporting Council regarding the preparation of integrated reports (IoDSA 2016).

Research has investigated the change and structure in the annual integrated report and results indicate that the size and proportion of voluntary information have increased and there has been a change in the use of alternate communication methods, such as graphs and pictures (Bartlett \& Jones 1997; Beattie, Dhanani \& Jones 2008b; Lee 1994). Companies are no longer focusing on the annual integrated report as being a statutory-driven document but rather as a design-orientated document, which functions as a public relations tool (Beattie et al. 2008b; Rahman, Hamdan \& Ibrahim 2014). The reasons companies use graphs in the annual integrated reports is discussed in the following section.

\section{Use of graphs}

Users find it difficult to read the reports because of the magnitude, complexity and technical jargon of the annual integrated reports and, at times, the information transmitted is of limited interest to the average shareholder (FrownfelterLohrke \& Fulkerson 2001; Rezaee \& Porter 1993). The use of graphs can overcome some of the problems. According to Beattie and Jones (2008a), companies seek to communicate using graphs for six reasons:

- Firstly, as graphs are not governed by standards and regulations, they allow management to present information in a more flexible manner.
- Secondly, graphs attract and capture attention as they are eye-catching because of their use of colour.

- Thirdly, graphs can summarise, refine and communicate financial information and can, in this way, enhance a reader's understanding of financial information (Beattie \& Jones 2008a; Falschlunger et al. 2015).

- Fourthly, graphs enable the reader to view the data more clearly and directly as they allow the reader to process information in graphic form.

- Fifthly, graphs are memorable, as pictorial and graphical representations are remembered much more vividly than numbers (Leivian 1980).

- Lastly, graphs do not have barriers relating to languages, accounting standards and the level of sophistication of users.

Graphs are a fascinating manner of communication, given the flexibility they allow preparers, as the values presented are audited but the actual graph is exempted from being audited (Beattie \& Jones 2000a; Steinbart 1989). The International Standard on Auditing (ISA) 720 discusses the auditor's responsibility relating to other information, such as graphs, which is to read this information to ensure that there are no material inconsistencies with the financial statements or with the auditor's prior knowledge. Apart from this, there is no other explicit standard specific to the use of graphs in annual integrated reports (Beattie \& Jones 1992; Burgess et al. 2008). It has therefore been argued that, as the employment of graphs is at the discretion of management, there may be deliberate misrepresentation of information (Beattie \& Jones 1992, 1997; De Klerk \& Van Wyk 2017). The manner in which graphs can be used to manipulate perceptions is presented in the following section.

\section{Impression management and the use of graphs}

Impression management can be viewed as the process by which individuals attempt to control the impressions of others and is the conscious or unconscious attempt to control images in a social setting (Leary \& Kowalski 1990; Schlenker 1980).

Impression management in corporate reporting occurs when management are able to control information disclosure in order to influence and manipulate users' attitudes towards and perceptions of the firm's performance, as advantage is taken of information asymmetries (Clatworthy \& Jones 2001; Merkl-Davies, Brennan \& McLeay 2011; Stanton, Stanton \& Pires 2004). Management are able to use their discretion regarding the information to reveal and present information in a manner that distorts the readers' perception of corporate achievements (Neu 1991; Neu, Warsame \& Pedwell 1998; Stanton et al. 2004). The result of impression management conflicts with the qualitative characteristics of the International Accounting Standards Board (IASB) (2018a) Conceptual Framework, as the information presented is no longer a faithful representation. This is because impression management results in information being presented that is no longer neutral and unbiased (Beattie \& Jones 2000b, 2008a). 
Impression management is found to occur in less regulated narrative disclosures, which focus on interpreting financial outcomes (Brennan, Guillamón-Saorín \& Pierce 2009). Impression management studies have investigated various aspects of the annual integrated reports that may be used as manipulation, such as the language used (Leung, Parker \& Courtis 2015), the use of imagery (Stanton \& Stanton 2002) and the chairman's statement (Clatworthy \& Jones 2001; Yasseen et al. 2017). Graphs have also been used as a tool of impression management as indicated in Table 2.

Impression management relating to graphs can occur in three ways according to Beattie and Jones (2008a), namely, selectivity, measurement distortion and presentational enhancement. Selectivity is the decision whether or not to use graphs within the annual integrated reports (Beattie \& Jones 1992). Selectivity occurs when only favourable and positive information is disclosed (Beattie \& Jones 2008a). Measurement distortion occurs where the physical representation of the numbers on the graph is not proportionate to the underlying numbers (Tufte 1983). Presentational enhancement occurs when the design of the graph components are changed to emphasise or understate certain features of the graph (Penrose 2008).

\section{Guidelines that can be considered for good graph design}

The effectiveness of graphs stems from the fact that users should be able to perceive the underlying relationship in the data being represented and, if this communication process fails, the impact of using a graph will be diminished (Cleveland 1985). In the study conducted by FrownfelterLohrke and Fulkerson (2001) a list was drawn up of 11 weaknesses in graphs and the corrective action, based on prior research conducted. The list is included in Table 1. Based on these principles, Frownfelter-Lohrke and Fulkerson (2001) developed a checklist, which identifies the guidelines for good graphs.

\section{Calculation of measurement distortion}

The fundamental principle of graph design is that the representation of numbers, as physically measured on the surface of the graph itself, should be directly proportional to the numerical values of the variables being represented (Tufte 1983). Therefore, measurement distortion occurs when the numerical values and the physical representation on the graph do not correspond (Beattie \& Jones 2002). Tufte measured this principle using the lie factor. The lie factor was modified by Taylor and Anderson (1986) to produce the graph discrepancy index (GDI), which is calculated as follows:

$\mathrm{GDI}=100 \times[(a-b)-1]$ or $[(a-b) / b] \times 100$

where $\mathrm{a}=\left(g_{2}-g_{1}\right) / g_{1}$ and $b=\left(d_{2}-d_{1}\right) / d_{1}$ $g_{1}$ and $g_{2}=$ the height of the first column and the last column in the graph in centimetre
TABLE 1: Weaknesses and corrective actions.

\begin{tabular}{|c|c|c|}
\hline Number & Weakness & Corrective action \\
\hline 1. & $\begin{array}{l}\text { Inadequate chart } \\
\text { titles and labels }\end{array}$ & $\begin{array}{l}\text { There must be clear labels and important events } \\
\text { should be highlighted (Jarett 1993; Tufte 1983). }\end{array}$ \\
\hline 2. & $\begin{array}{l}\text { No numerical } \\
\text { labels }\end{array}$ & $\begin{array}{l}\text { The specifier should display the corresponding } \\
\text { number above the column and there should be no } \\
\text { data inside the bar (Jarett 1993). }\end{array}$ \\
\hline 3. & $\begin{array}{l}\text { Obtrusive } \\
\text { backgrounds with } \\
\text { no clearly defined } \\
\text { borders }\end{array}$ & $\begin{array}{l}\text { The background should not be patterned or } \\
\text { brightly coloured and there should be borders } \\
\text { (Jarett 1993; Tufte 1983). }\end{array}$ \\
\hline 4. & Optical illusions & $\begin{array}{l}\text { The graphs should be two-dimensional (Tufte } \\
\text { 1983). }\end{array}$ \\
\hline 5. & $\begin{array}{l}\text { Inappropriate } \\
\text { colour }\end{array}$ & $\begin{array}{l}\text { There should be a maximum of six colours and a } \\
\text { legend should be included (Jarett \& Babad 1988). }\end{array}$ \\
\hline 6. & $\begin{array}{l}\text { Trendy visual } \\
\text { effects }\end{array}$ & $\begin{array}{l}\text { Graphs should be simply designed and } \\
\text { unnecessary decoration avoided (Tufte 1983). }\end{array}$ \\
\hline 7. & $\begin{array}{l}\text { Baselines and/or } \\
\text { data markers that } \\
\text { do not begin at a } \\
\text { zero baseline }\end{array}$ & $\begin{array}{l}\text { Scales should begin at zero and should be } \\
\text { continuous (CICA 1993). }\end{array}$ \\
\hline 8. & $\begin{array}{l}\text { Multiple scales on } \\
\text { the vertical axis }\end{array}$ & $\begin{array}{l}\text { There should be one scale as multiple scales cause } \\
\text { ambiguity (CICA 1993). }\end{array}$ \\
\hline 9. & $\begin{array}{l}\text { Time series data } \\
\text { portrayed in } \\
\text { reverse order }\end{array}$ & $\begin{array}{l}\text { When a time series is in reverse order it is difficult } \\
\text { for the user to assess the actual trend (Tufte } \\
\text { 1983). }\end{array}$ \\
\hline 10. & $\begin{array}{l}\text { Exaggerated width } \\
\text { of data markers or } \\
\text { spaces }\end{array}$ & $\begin{array}{l}\text { Bars should be uniform and evenly spaced (Tufte } \\
\text { 1983). }\end{array}$ \\
\hline 11. & $\begin{array}{l}\text { Overextended } \\
\text { scales }\end{array}$ & $\begin{array}{l}\text { The depiction of the graph should be directly } \\
\text { proportional to any changes in the numerical } \\
\text { values. (Tufte 1983). }\end{array}$ \\
\hline
\end{tabular}

Source: Frownfelter-Lohrke, C., \& Fulkerson, C.L., 2001, 'The incidence and quality of graphics in annual reports: An international comparison', The Journal of Business Communication 38(3), 337-358. https://doi.org/10.1177/002194360103800308

$d_{1}$ and $d_{2}=$ data for the first column and the last column in the graph

$a=$ percentage change depicted in graph

$b=$ percentage change depicted in data

The GDI assists with evaluating whether trends are exaggerated or understated. In the absence of measurement distortion, the index is zero (Penrose 2008). Positive (negative) GDI values represent the magnitude by which the trend portrayed in the graph is exaggerated (understated).

\section{Results of graph use from other studies}

Table 2 summarises the prior research conducted on graphs in annual integrated reports.

\section{Methodology}

The study conducted has been framed within a positivist research paradigm using a descriptive quantitative research method. The data used in the study were obtained from the annual integrated reports of listed companies, which resulted in no interaction with research participants, therefore enhancing objectivity (Dudovskiy 2018; Hallebone \& Priest 2009; Wahyuni 2012). The data collected were numerical and analysed using statistical means, resulting in the research approach being quantitative (Leedy \& Ormrod 2015; Wahyuni 2012).

The top 100 companies listed on the main board of the JSE were selected as the sample for the financial year ending 2017. During the collection of data, annual integrated reports relating to two companies were excluded from the sample. The first company is a dual-listed structure, which comprises 
TABLE 2: Overview of prior studies conducted.

\begin{tabular}{|c|c|c|c|c|c|c|}
\hline Study & $\begin{array}{l}\text { Population and } \\
\text { year examined }\end{array}$ & Sample size & $\begin{array}{l}\text { Percent of annual } \\
\text { reports containing } \\
\text { graphs (\%) }\end{array}$ & $\begin{array}{l}\text { Percent of improperly } \\
\text { constructed graphs } \\
(\%)\end{array}$ & $\begin{array}{l}\text { Material distortion } \\
\text { cut-off }(\%)\end{array}$ & Average GDI (\%) \\
\hline \multicolumn{7}{|l|}{ North America } \\
\hline \multirow[t]{2}{*}{$\begin{array}{l}\text { Frownfelter-Lohrke } \\
\text { and Fulkerson (2001) }\end{array}$} & $\begin{array}{l}\text { Companies listed on the } \\
\text { New York and American }\end{array}$ & $\begin{array}{l}37-\text { US listed } \\
\text { companies }\end{array}$ & US companies - 89 & Not provided & Not provided & US companies - 81 \\
\hline & $\begin{array}{l}\text { Stock Exchange for the } \\
\text { period 1984-1994 }\end{array}$ & $\begin{array}{l}37 \text { - Non- US listed } \\
\text { cocpanies }\end{array}$ & Non-US companies - 86 & - & - & $\begin{array}{l}\text { Non-US companies - } \\
173\end{array}$ \\
\hline \multicolumn{7}{|l|}{ Europe } \\
\hline $\begin{array}{l}\text { Beattie and Jones } \\
\text { (1992) }\end{array}$ & $\begin{array}{l}\text { UK Large Listed companies } \\
\text { by capitalisation for } 1989\end{array}$ & 240 & 79 & 30.5 & 5 & 10.7 \\
\hline Uyar (2009) & $\begin{array}{l}\text { Companies listed on the } \\
\text { Istanbul Stock Exchange for } \\
2006\end{array}$ & 96 & 75 & $\begin{array}{l}\text { Distortion was not } \\
\text { analysed in detail }\end{array}$ & $\begin{array}{l}\text { Distortion was not } \\
\text { analysed in detail }\end{array}$ & $\begin{array}{l}\text { Distortion was not } \\
\text { analysed in detail }\end{array}$ \\
\hline \multirow{3}{*}{$\begin{array}{l}\text { Falschlunger et al. } \\
\text { (2015) }\end{array}$} & \multirow{3}{*}{$\begin{array}{l}\text { Top } 50 \text { European } \\
\text { Companies on the Fortune } \\
500 \text { index for 2006, } 2009 \\
\text { and } 2012\end{array}$} & \multirow[t]{3}{*}{50} & $2006-97.7$ & \multirow[t]{3}{*}{43.2} & \multirow[t]{3}{*}{5} & \multirow[t]{3}{*}{773.2} \\
\hline & & & $2009-100$ & & & \\
\hline & & & $2012-100$ & & & \\
\hline \multicolumn{7}{|c|}{ North America and Europe } \\
\hline \multirow{2}{*}{$\begin{array}{l}\text { Beattie and Jones } \\
\text { (1997) }\end{array}$} & \multirow{2}{*}{$\begin{array}{l}\text { Largest based on sales of } \\
100 \text { UK and US companies } \\
\text { for } 1990\end{array}$} & 85 UK and & UK -80 & UK - 24 & \multirow[t]{2}{*}{5} & UK -7 \\
\hline & & 91 US Companies & US - 92 & US - 24 & & US - 16 \\
\hline \multicolumn{7}{|l|}{ Australia } \\
\hline $\begin{array}{l}\text { Beattie and Jones } \\
\text { (1999) }\end{array}$ & $\begin{array}{l}\text { Top } 100 \text { Companies listed } \\
\text { on the Australian Stock } \\
\text { Exchange for } 1991\end{array}$ & 89 & 89 & 34 & 5 & 10.5 \\
\hline \multicolumn{7}{|l|}{ Asia } \\
\hline \multirow[t]{4}{*}{ Rahman et al. (2014) } & \multirow{4}{*}{$\begin{array}{l}\text { Non-financial public listed } \\
\text { companies on the Kuala } \\
\text { Lumpur Stock Exchange for } \\
30 \text { years using a 10-year } \\
\text { interval }\end{array}$} & \multirow[t]{4}{*}{54} & $1974-15$ & \multirow[t]{4}{*}{ Not considered } & \multirow[t]{4}{*}{ Not considered } & \multirow[t]{4}{*}{ Not considered } \\
\hline & & & $1984-31$ & & & \\
\hline & & & $1994-59$ & & & \\
\hline & & & $2004-65$ & & & \\
\hline \multicolumn{7}{|l|}{ Africa } \\
\hline $\begin{array}{l}\text { De Klerk and Van Wyk } \\
\text { (2017) }\end{array}$ & $\begin{array}{l}\text { Mining companies listed on } \\
\text { the JSE for } 2010-2013\end{array}$ & 28 & 86 & 1 & Not disclosed & Not disclosed \\
\hline
\end{tabular}

GDI, graph discrepancy index; JSE, Johannesburg Stock Exchange.

a UK and South African incorporated company with both companies listed on the JSE. The same integrated annual integrated report is produced for both companies. The second company did not have an annual integrated report available because of the restatement of its financial statements.

\section{Analysis plan - Data collection and data analysis}

An Excel spreadsheet was used to record information in terms of company name, market capitalisation, sector, type of graphs, variables of graphs, the guidelines for good graphs and the calculation of GDI. The variables relating to graphs were split between key financial variable (KFV) graphs, other financial graphs and non-financial graphs. Key financial variable graphs relate to profits, earnings per share (EPS) and dividends per share (DPS), which is consistent with prior studies conducted (Beattie \& Jones 1992, 1999; Mather et al. 2005).

\section{Frequency of graphs in the annual integrated report and subject matter of graphs included in the annual integrated report}

In addressing Research Questions 1 and 2, the number of graphs that appear in the annual integrated report of listed entities was manually counted and recorded in an Excel spreadsheet. Each graph was classified as either a financial graph or a non-financial graph. Graphs were also classified in terms of the type of graph, according to the following categories obtained from Frownfelter-Lohrke and Fulkerson (2001): column (column is vertical), bar (column is horizontal), line, pie diagram, stacked bar or column, area, combination of line-bar, etc..

\section{Compliance with standards for good graphs in the annual integrated reports}

At the present time there are no mandated standards for the creation and presentation of graphs but, in order to address Research Question 3, there is research that provides guidelines on good graphs. Frownfelter-Lohrke and Fulkerson (2001) developed a checklist that identifies the guidelines for good graphs, based on prior research. Beattie and Jones (1997) used the principles dictated by Kosslyn (1989) to measure the compliance with guidelines. These are similar to the principles noted by FrownfelterLohrke and Fulkerson (2001). For this study, the checklist created by Frownfelter-Lohrke and Fulkerson (2001) was used, but additional guidelines were incorporated, based on the checklist developed by Beattie and Jones (1997; Table 5).

Both financial and non-financial graphs were analysed for compliance. Certain questions were not applicable to all types of graphs. For instance, the inclusion of an axis was not considered for pie charts. Each question was answered by a Yes, No or Not applicable response and counted on Excel. Instances of not applicable resulted in cases where there was a No answer to the over-arching question. For example, if a graph did not have a financial axis, the location of the axis would not be an applicable question. 


\section{Level of distortion for graphs included in the annual integrated reports}

Measurement distortion occurs when the numerical values and the physical representation on the graph do not correspond (Beattie \& Jones 2002). Tufte measured this principle using the lie factor and this was modified by Taylor and Anderson (1986) to produce the GDI.

In terms of determining material measurement distortion, Tufte (1983) suggested that values of GDI above 5\% are material exaggeration and values below $5 \%$ are material understatement. In the studies conducted by Mather et al. (2005) and Beattie and Jones (1992,1997), a figure of greater or less than and equal to $5 \%$ was used based on the conclusions of Pany and Wheeler (1989). For the purposes of this study, the established measures of $\geq 5 \%$ and $\leq 5 \%$ were used to determine if there was material distortion.

To address Research Question 4, measurement distortion was calculated using the GDI formula on Excel for all graphs, which fall within the following types: bar, column, line, combination of line-bar and the stacked bar or column. The heights of GDI were measured to the nearest millimetre and were converted to centimetres to comply with the formula.

\section{Validity and reliability}

In this study, content validity was achieved as the measures used for each research question enabled the researcher to reach a conclusion and allowed all the research questions to be answered (Patrick 2009). The research questions were obtained from a replicated study, which further ensured that the research questions and measures were appropriately aligned. Reliability can be described as whether the instrument used in the research study can consistently measure what it is intended to measure (Patrick 2009). Reliability is achieved as the data collection instrument can be consistently used to answer the research questions. In addition, the criteria used to determine presentational enhancement is consistently applied for each graph examined (Galpin \& Krommenhoek 2013), ensuring the validity of the results.

\section{Ethical consideration}

Ethical clearance was given for this study by the University of the Witwatersrand under clearance number CACCN/1164 on 2018/08/28.

\section{Analysis and results Descriptive statistics}

The results indicate that 96 companies (98\%) out of 98 used graphic disclosure. The total number of graphs included in the annual integrated reports amounted to 4008 graphs. The average number of graphs amounted to 40.9 graphs per annual integrated report.

\section{Graphic disclosure per sector}

The Basic Resources Sector had most graphs, where 934 graphs $(23.3 \%$ of the total) were found, followed by Real Estate where 597 (14.9\%) graphs were found and followed by the Banking Sector where $471(11.8 \%)$ graphs were found. Table 3 provides a sector analysis in terms of graph usage and number of companies.

\section{Types of graph}

The three most frequently used graphs are the column graph $(34 \%)$, pie chart $(24 \%)$ and bar graph $(12 \%)$. Other graphs included pictorial graphs, scatter plots and bubble graphs. In general, graphs, especially column graphs, are able to convey information simply and effectively, which may be the reason why column graphs are mostly used (Harris 2000). In terms of the types of graph used for financial and non-financial graphs the results are similar. The column graph is the most prevalent graph for both the financial and non-financial category as shown in Table 4.

TABLE 3: Sector analysis as per the Johannesburg Stock Exchange.

\begin{tabular}{|c|c|c|c|c|c|}
\hline Sector & $\begin{array}{c}\text { Number of } \\
\text { graphs per sector }\end{array}$ & $\begin{array}{l}\text { Percentage of graphs } \\
\text { per sector }(\%)\end{array}$ & $\begin{array}{l}\text { Number of } \\
\text { companies }\end{array}$ & $\begin{array}{c}\text { Number of companies - } \\
\text { percentage }(\%)\end{array}$ & $\begin{array}{l}\text { Average per company } \\
\text { per sector }\end{array}$ \\
\hline Basic resources & 934 & 23.3 & 17 & 17.3 & 54.9 \\
\hline Real estate & 597 & 14.9 & 15 & 15.3 & 39.8 \\
\hline Banks & 471 & 11.8 & 6 & 6.1 & 78.5 \\
\hline Retail & 299 & 7.5 & 14 & 14.3 & 21.4 \\
\hline Healthcare & 288 & 7.2 & 5 & 5.1 & 57.6 \\
\hline Financial services & 283 & 7.1 & 8 & 8.2 & 35.4 \\
\hline Industrial goods and services & 245 & 6.1 & 7 & 7.1 & 35.0 \\
\hline Insurance & 241 & 6.0 & 6 & 6.1 & 40.2 \\
\hline Chemicals & 164 & 4.1 & 2 & 2.0 & 82.0 \\
\hline Food and beverage & 162 & 4.0 & 8 & 8.2 & 20.3 \\
\hline Telecommunications & 152 & 3.8 & 3 & 3.1 & 50.7 \\
\hline Personal and household goods & 76 & 1.9 & 2 & 2.0 & 38.0 \\
\hline Media & 42 & 1.0 & 1 & 1.0 & 42.0 \\
\hline Construction and materials & 32 & 0.8 & 1 & 1.0 & 32.0 \\
\hline Travel and leisure & 20 & 0.5 & 1 & 1.0 & 20.0 \\
\hline Investment instruments & 2 & 0.0 & 1 & 1.0 & 2.0 \\
\hline Technology & 0 & 0.0 & 1 & 1.0 & 0.0 \\
\hline Total & 4008 & 100 & 98 & 100 & 40.9 \\
\hline
\end{tabular}




\section{Variables graphed}

The use of financial and non-financial graphs is a means of communication by which companies inform users of the different aspects of a company's performance (Uyar 2009). South African listed companies present more financial graphs, with 2458 (61.3\%) financial graphs being disclosed, compared with $1550(38.7 \%)$ non-financial graphs presented.

In terms of financial graphs, the category 'Other' had the most graphs at $45 \%$. In terms of the KFV, sales were the most graphed category (9\%), followed by profit (3\%), EPS (2\%) and DPS (1\%). Regarding the category 'Other', the type of graphs included relates to variations of earnings: operating cash flow information such as free cash flow, borrowings of the company and expenses incurred.

In terms of non-financial graphs, various types of non-financial information are disclosed. The disclosure in non-financial graphs could be attributed to the introduction of integrated reporting.

\section{Compliance with standards for good graphs}

This section discusses the level of presentational enhancement exhibited by the graphs disclosed. The analysis is based on the questions included in Table 5. The questions were based on the study completed by

TABLE 4: Graph type by category.

\begin{tabular}{|c|c|c|c|c|c|}
\hline \multicolumn{3}{|l|}{ Financial } & \multicolumn{3}{|c|}{ Non-financial } \\
\hline Type & Number of graphs & $\%$ & Type & Number of graphs & $\%$ \\
\hline Column & 873 & 35.5 & Column & 501 & 32.3 \\
\hline Pie & 509 & 20.7 & Pie & 438 & 28.3 \\
\hline Line & 311 & 12.7 & Bar & 200 & 12.9 \\
\hline Bar & 263 & 10.7 & Line & 143 & 9.2 \\
\hline Combination line/bar/column & 215 & 8.7 & Combination line/bar/column & 105 & 6.8 \\
\hline Other & 83 & 3.4 & Stacked column & 51 & 3.3 \\
\hline Area & 29 & 1.2 & Area & 14 & 0.9 \\
\hline Stacked bar & 18 & 0.7 & Stacked bar & 2 & 0.1 \\
\hline Total & 2458 & 100.0 & Total & 1550 & 100.0 \\
\hline
\end{tabular}

TABLE 5: South African companies' compliance with good graph guidelines.

\begin{tabular}{|c|c|c|c|c|c|}
\hline Question & Guidelines & $\begin{array}{l}\text { Findings - Current } \\
\text { study (\%) }\end{array}$ & $\begin{array}{c}\text { Applicable to all graphs (If not } \\
\text { selected pie diagrams are excluded) }\end{array}$ & $\begin{array}{l}\text { Frownfelter-Lohrke and } \\
\text { Fulkerson (2001) }\end{array}$ & $\begin{array}{l}\text { Beattie and } \\
\text { Jones (1997) }\end{array}$ \\
\hline 1 & Inadequate chart titles and labels & & & & \\
\hline \multirow[t]{2}{*}{1.1} & Is the graph detailed and labelled? (Yes) & 99 & $\checkmark$ & $\checkmark$ & - \\
\hline & Is the graph detailed and labelled? (No) & 1 & $\checkmark$ & $\checkmark$ & - \\
\hline \multirow[t]{4}{*}{1.2} & Are important events labelled? (Yes) & 99 & $\checkmark$ & $\checkmark$ & - \\
\hline & Are important events labelled? (No) & 1 & $\checkmark$ & $\checkmark$ & - \\
\hline & Axis & - & - & - & - \\
\hline & Numeric scale & - & - & - & - \\
\hline \multirow[t]{2}{*}{1.3} & Is there a scaled financial variable axis? (Yes) & 61 & - & - & $\checkmark$ \\
\hline & Is there a scaled financial variable axis? (No) & 39 & - & - & $\checkmark$ \\
\hline \multirow[t]{4}{*}{1.4} & Where is the financial variable axis located? & - & - & - & $\checkmark$ \\
\hline & Conventionally - Left & 95 & - & - & - \\
\hline & Unconventionally - Right & 5 & - & - & - \\
\hline & Specifier - The column which represents the numeric values & - & - & - & - \\
\hline \multirow[t]{2}{*}{1.5} & Is there a number attached to the specifier? (Yes) & 73 & $\checkmark$ & - & $\checkmark$ \\
\hline & Is there a number attached to the specifier? (No) & 27 & $\checkmark$ & - & $\checkmark$ \\
\hline \multirow[t]{3}{*}{1.6} & Is the numeric label on the specifier horizontal? (Yes) & 78 & - & - & $\checkmark$ \\
\hline & Is the numeric label on the specifier horizontal? (No) & 22 & - & - & $\checkmark$ \\
\hline & Scale & - & - & - & - \\
\hline \multirow[t]{3}{*}{1.7} & Is the scale continuous or broken? & - & - & $\checkmark$ & - \\
\hline & Continuous (Yes) & 100 & - & - & - \\
\hline & Broken (No) & 0 & - & - & - \\
\hline \multirow[t]{3}{*}{1.8} & Does the scale begin at zero? (Yes) & 91 & - & $\checkmark$ & - \\
\hline & Does the scale begin at zero? (No) & 9 & - & $\checkmark$ & - \\
\hline & Time axis & - & - & - & - \\
\hline \multirow[t]{2}{*}{1.9} & Is there a scaled time axis? (Yes) & 84 & - & - & $\checkmark$ \\
\hline & Is there a scaled time axis? (No) & 16 & - & - & $\checkmark$ \\
\hline \multirow[t]{3}{*}{1.10} & Is the numeric label on the time axis horizontal? (Yes) & 78 & - & - & $\checkmark$ \\
\hline & Is the numeric label on the time axis horizontal? (No) & 22 & - & - & $\checkmark$ \\
\hline & Gridlines & - & - & - & - \\
\hline
\end{tabular}


TABLE 5 (Continues...): South African companies' compliance with good graph guidelines.

\begin{tabular}{|c|c|c|c|c|c|}
\hline Question & Guidelines & $\begin{array}{l}\text { Findings - Current } \\
\text { study }(\%)\end{array}$ & $\begin{array}{l}\text { Applicable to all graphs (If not } \\
\text { selected pie diagrams are excluded) }\end{array}$ & $\begin{array}{l}\text { Frownfelter-Lohrke and } \\
\text { Fulkerson (2001) }\end{array}$ & $\begin{array}{l}\text { Beattie and } \\
\text { Jones (1997) }\end{array}$ \\
\hline \multirow[t]{2}{*}{1.11} & Are gridlines included? (Yes) & 18 & - & - & $\checkmark$ \\
\hline & Are gridlines included? (No) & 82 & - & - & $\checkmark$ \\
\hline \multirow[t]{9}{*}{2} & Obtrusive backgrounds & & & & \\
\hline & What colour is the background of the graph? & - & $\checkmark$ & $\checkmark$ & - \\
\hline & White & 81 & - & - & - \\
\hline & Grey & 12 & - & - & - \\
\hline & Yellow & 0 & - & - & - \\
\hline & Beige/Ivory & 3 & - & - & - \\
\hline & Black & 0 & - & - & - \\
\hline & Other colours & 2 & - & - & - \\
\hline & Picture & 2 & - & - & - \\
\hline \multirow[t]{2}{*}{3} & Borders & & & & \\
\hline & Are there clearly defined borders? (Yes) & 100 & - & $\checkmark$ & - \\
\hline \multirow[t]{3}{*}{4} & Optical illusion & & & & \\
\hline & Is the graph three-dimensional? (Yes) & 2 & $\checkmark$ & $\checkmark$ & - \\
\hline & Is the graph three-dimensional? (No) & 98 & $\checkmark$ & $\checkmark$ & - \\
\hline \multirow[t]{4}{*}{5} & Inappropriate use of colour & - & - & - & - \\
\hline & How many colours are in the graph? & - & - & - & - \\
\hline & Fewer than $6(<6)$ & 96 & $\checkmark$ & $\checkmark$ & - \\
\hline & More than $6(>6)$ & 4 & $\checkmark$ & $\checkmark$ & - \\
\hline \multirow[t]{3}{*}{6} & Legend & & & & \\
\hline & Is there a legend? (Yes) & 91 & $\checkmark$ & $\checkmark$ & - \\
\hline & Is there a legend? (No) & 9 & $\checkmark$ & $\checkmark$ & - \\
\hline 7 & Trendy visual effects & & & & \\
\hline \multirow[t]{2}{*}{7.1} & Do borders detract from the graph? (Yes) & 0 & $\checkmark$ & $\checkmark$ & - \\
\hline & Do borders detract from the graph? (No) & 100 & $\checkmark$ & $\checkmark$ & - \\
\hline 7.2 & Are there any data inside the graph? (Yes) & 35 & $\checkmark$ & $\checkmark$ & - \\
\hline \multirow{3}{*}{8} & Is there a single scale or multiple scale? & - & - & - & - \\
\hline & Single & 97 & - & $\checkmark$ & - \\
\hline & Multiple scale on the vertical axis & 3 & - & $\checkmark$ & - \\
\hline \multirow[t]{4}{*}{9} & Time series portrayed in reverse order & & & & \\
\hline & $\begin{array}{l}\text { Are the data on the graph in sequential or reverse sequential } \\
\text { order? }\end{array}$ & - & - & $\checkmark$ & - \\
\hline & Sequential & 86 & - & $\checkmark$ & - \\
\hline & Reverse & 14 & - & $\checkmark$ & - \\
\hline \multirow[t]{3}{*}{10} & Exaggerated width of data markers or spaced & & & & \\
\hline & Are the bars of uniform width and evenly spaced? (Yes) & 100 & - & $\checkmark$ & - \\
\hline & Are the bars of uniform width and evenly spaced? (No) & 0 & - & $\checkmark$ & - \\
\hline
\end{tabular}

Frownfelter-Lohrke and Fulkerson (2001); however, additional questions were obtained from the study completed by Beattie and Jones (1997). The source of each question is indicated.

Presentational enhancement was found to some extent in the graphs presented in the annual integrated reports of South African listed entities. The largest non-compliance related to the omission of gridlines (82\%). Graphs did not always disclose a scaled financial variable axis (39\%), which makes it difficult for a user to gather accurate information (Frownfelter-Lohrke \& Fulkerson 2001). Having a specifier on a graph allows users to analyse trends and relationships, however $27 \%$ of graphs did not include a specifier. Fourteen percent (14\%) of graphs disclosed the time sequence in reverse order, which can cause confusion as data are not presented according to traditional norms
(Arunachalam, Pei \& Steinbart 2002). These were the major breaches found in the graphs presented. South African listed companies do not appear to use obtrusive background colours or three-dimensional graphs, as only $2 \%$ of graphs included these effects. Overall, there is some noncompliance with good graph standards, but South African listed companies do not appear to use presentational enhancement as a medium of distortion.

\section{Measurement of distortion - Graph discrepancy index}

Of the 4008 graphs, there were no data available for 807 graphs (as the specifier did not have a number attached to it). Regarding 1092 graphs, the GDI could not be calculated because of the nature of the graph. This resulted in the GDI being calculated for 2109 graphs: this is the sample used for the analysis. 
TABLE 6: Analysis of the number of graphs distorted.

\begin{tabular}{|c|c|c|c|c|c|c|}
\hline Variable & $\begin{array}{l}\text { Materially } \\
\text { distorted }\end{array}$ & $\%$ & $\begin{array}{l}\text { Not distorted or } \\
\text { not materially } \\
\text { distorted }\end{array}$ & $\%$ & Total & $\%$ \\
\hline \multicolumn{7}{|l|}{ Financial } \\
\hline Sales & 84 & 4.0 & 36 & 1.7 & 120 & 5.7 \\
\hline EPS & 37 & 1.8 & 27 & 1.3 & 64 & 3.0 \\
\hline DPS & 27 & 1.3 & 14 & 0.7 & 41 & 1.9 \\
\hline Profit & 36 & 1.7 & 26 & 1.2 & 62 & 2.9 \\
\hline Other financial & 724 & 34.3 & 309 & 14.7 & 1033 & 49.0 \\
\hline Total financial & 908 & 43.1 & 412 & 19.5 & 1320 & 62.6 \\
\hline Non-financial & 531 & 25.2 & 258 & 12.2 & 789 & 37.4 \\
\hline Total & 1439 & 68.2 & 670 & 31.8 & 2109 & 100.0 \\
\hline
\end{tabular}

DPS, dividends per share; EPS, earnings per share.

\section{Graphs distorted}

A total of 1439 graphs (68.2\%) were materially distorted. The remainder 670 graphs $(31.8 \%)$ were either not distorted or were not materially distorted. Table 6 provides an analysis of the graphs distorted per variable.

\section{Material exaggeration or understatement}

Graphs tend to exaggerate the trend (57.1\%) as opposed to understating it $(42.9 \%)$. Financial graphs have the highest number of discrepancies for exaggeration (35.6\%) and understatement (27.4\%). Non-financial graphs contain both exaggerated $(21.4 \%)$ and understated (15.5\%) trends, but on a lesser scale. In all instances, apart from the EPS variable, the number of graphs exaggerated exceeded the number of graphs understated.

\section{Average graph discrepancy index}

There appears to be significant measurement distortion for both financial and non-financial graphs. The overall average GDI for all graphs was $134 \%$, resulting in material measurement distortion. The average GDI for material exaggeration is higher $(304.8 \%)$ when compared to material understatement $(-92.8 \%)$.

Financial graphs have an average GDI of $121.6 \%$, indicating that trends are materially overstated. Non-financial graphs also displayed exaggeration in trends as the average GDI was $155.2 \%$, which is higher when compared to financial graphs.

Based on these facts, it can be concluded that impression management for graphs of South African companies materially overstate the information displayed to create a more favourable impression of the company to users.

Analysis of distortion per variable: If the average GDI is analysed per variable the results indicate that for KFV, profit is the variable most exaggerated as it has the highest average GDI (563.5\%), followed by DPS (403.9\%), sales (222.4\%) and EPS (112.1\%). In terms of the type of distortion, the average GDI for material exaggeration exceeded the average GDI for understatement for all variables analysed. Table 7 provides information on the GDI calculated per variable.
TABLE 7: Average graph discrepancy index per variable.

\begin{tabular}{lccc}
\hline Variable & $\mathbf{2 5 \%}$ & $\mathbf{5 \%}$ & Average \\
\hline Financial & & & \\
Sales & 222.4 & -47.1 & 110.1 \\
EPS & 112.1 & -61.6 & 18.2 \\
DPS & 403.9 & -39.5 & 256.1 \\
Profit & 563.5 & -73.7 & 368.8 \\
Other financial & 283.3 & -106.8 & 110.9 \\
Total financial & $\mathbf{2 8 9 . 7}$ & $\mathbf{- 9 6 . 7}$ & $\mathbf{1 2 1 . 6}$ \\
Non-financial & $\mathbf{3 2 9 . 8}$ & $\mathbf{- 8 5 . 9}$ & $\mathbf{1 5 5 . 2}$ \\
\hline Total & $\mathbf{3 0 4 . 8}$ & $\mathbf{- 9 2 . 8}$ & $\mathbf{1 3 4 . 0}$ \\
\hline
\end{tabular}

DPS, dividends per share; EPS, earnings per share.

\section{Conclusion}

Prior research has indicated that there has been a change in the format of the traditional annual reports as the volume of voluntary information has increased, and there is a change in the use of alternate means of communication, such as graphs, tables and pictures (Bartlett \& Jones 1997; Beattie et al. 2008b; Lee 1994). As a result, elements of management bias that result in impression management may be found within sections of the reports in an attempt to provide a more favourable image of management. For the purpose of this study, the use of graphs as a tool of impression management was investigated.

One of the visual representations identified as becoming a popular means of communication is the use of graphs. Graphs have the ability to summarise information and readers can process information in graphic form, which saves time in analysing data and enhances understanding (Beattie \& Jones 2008a; Frownfelter-Lohrke \& Fulkerson 2001). Although there are advantages, the use of graphs is not problem-free as it can be a means by which management manipulates the information disclosed to create a better impression, which may be deceptive (Beattie \& Jones 1999, 2008a). Impression management relating to graphs can occur in three ways according to Beattie and Jones (2008a), namely selectivity, measurement distortion and presentational enhancement. For the purpose of this study, measurement distortion and presentational enhancement were investigated.

The use of graphs was found to be widespread amongst companies listed on the JSE, as $98 \%$ of companies presented graphs, with an average of 40.9 graphs per annual integrated report. A total of 4008 graphs were presented. The column graph was found to be the most common type of graph. Regarding KFV graphs, sales is the variable that was mostly used for creating graphs, followed by profit, EPS and DPS. Non-financial graph disclosure displays a variety of information, such as the water use of companies, carbon emissions, race and gender of employees.

Similar to other countries, the graphs presented by South African listed companies have some level of presentational enhancement. The most widespread non-compliance appears to be that graphs do not include gridlines (82\%). Graphs omit the scaled financial variable axis (39\%) and exclude the 
specifier (35\%), which can make it difficult for a user to gather accurate information (Frownfelter-Lohrke \& Fulkerson 2001). Fourteen per cent of the graphs disclosed time sequence in a reverse, which may cause confusion to a reader (Arunachalam et al. 2002), and 3\% of graphs had a multiple axis. In terms of using visual effects, the graphs of South African listed companies appear to avoid visual effects, as only $2 \%$ of graphs were three-dimensional and had obtrusive backgrounds. Most graphs had six or fewer colours. Overall, there is some non-compliance with good graph standards, but South African companies do not appear to use presentational enhancement as a medium of distortion relating to graphs.

Measurement distortion occurs where the physical representation of the numbers on the graph is not proportionate to the underlying numbers (Tufte 1983). For the purpose of this study, significant measurement distortion was considered for GDI that was $\geq 5 \%$ or $\leq 5 \%$. In total, GDI was calculated for 2109 graphs. Of the 2109 graphs, 1439 graphs $(68.2 \%)$ were materially distorted. Financial graphs had a greater percentage of materially distorted graphs $(63.1 \%)$ than non-financial graphs (36.9\%).

In terms of exaggeration $(\geq 5 \%)$ or understatement $(\leq 5 \%)$ of trends, it was found that graphs tend to exaggerate the trend (57.1\%) to a larger extent than understate (42.9\%). In terms of exaggeration, more financial graphs $(35.6 \%)$ display material exaggeration than non-financial graphs (21.4\%). The same results were found for material understatement as more financial graphs (27.4\%) displayed an understated trend than non-financial graphs (15.5\%). The average GDI was calculated as $134 \%$ for all graphs, which implies that graphs tend to overstate the trend by $134 \%$. This once again supports the statement that South African listed companies use graphs as a tool of impression management, particularly to portray a favourable image of the company to users of the annual integrated reports.

The study is limited as the annual integrated report comprises various disclosures, and this research study is limited to only examining the use of graphs within the annual integrated reports. The companies investigated are all listed on the main board of JSE and the findings may not be representative of smaller companies. Selectivity as a means of impression management was not considered when analysing graphs.

This study can be extended by analysing for a longer time period, which will allow selectivity to be examined. An analysis could be performed on companies with a smaller market share, such as companies listed on the AltX. The public sector could be examined to identify if there are any significant differences when comparing the two sectors.

\section{Acknowledgements}

The authors would like to thank Professor Nirupa Padia for her guidance.

\section{Competing interests}

The authors have declared that no competing interest exists.

\section{Authors' contributions}

Z.V. is the primary author; she executed the research and composed the article. Y.Y. provided key insight and made key contributions to the design, analysis and interpretation of data whilst the article was being written.

\section{Funding information}

The research received no specific grant from any funding agency in the public, commercial or not-for-profit sectors.

\section{Data availability statement}

The data that support the findings of this study are available on request from the corresponding author, Zakiyyah Varachia.

\section{Disclaimer}

The views and opinions expressed in this article are those of the authors and do not necessarily reflect the official policy or position of any affiliated agency of the authors.

\section{References}

Arunachalam, V., Pei, B.K.W., \& Steinbart, P.J., 2002, 'Impression management with graphs: Effects on choices', Journal of Information Systems 16(2), 183-202. https://doi.org/10.2308/jis.2002.16.2.183

Atkins, J., \& Maroun, W., 2015, 'Integrated reporting in South Africa in 2012 Perspectives from South African institutional investors', Meditari Accountancy Research 23(2), 197-221. https://doi.org/10.1108/MEDAR-07-2014-0047

Bartlett, S., \& Jones, M.J., 1997, 'Annual reporting disclosures 1970-1990: An exemplification', Accounting, Business and Financial History 7(1), 61-80. https:// doi.org/10.1080/095852097330766

Beattie, V., Dhanani, A., \& Jones, M.J., 2008b, 'Investigating presentational change in U.K. annual reports: A longitudinal perspective', The Journal of Business Communication (1973) 45(2), 181-222. https://doi.org/10.1177/0021943607313993

Beattie, V., \& Jones, M.J., 1992, 'The use and abuse of graphs in annual reports: Theoretical framework and empirical study', Accounting and Business Research 22(88), 291-303. https://doi.org/10.1080/00014788.1992.9729446

Beattie, V., \& Jones, M.J., 1997, 'A comparative study of the use of financial graphs in the corporate annual reports of major U.S. and U.K. companies', Journal of International Financial Management and Accounting 8(1), 33-68. https://doi. org/10.1111/1467-646X.00016

Beattie, V., \& Jones, M.J., 1999, 'Australian financial graphs: An empirical study', Abacus 35(1), 46-76. https://doi.org/10.1111/1467-6281.00034

Beattie, V., \& Jones, M.J., 2000a, 'Changing graph use in corporate annual reports: A time-series analysis', Contemporary Accounting Research 17(2), 213-226. https:// doi.org/10.1506/AAT8-3CGL-3J94-PH4F

Beattie, V., \& Jones, M.J., 2000b, 'Impression management: The case of inter-country financial graphs', Journal of International Accounting, Auditing \& Taxation 9(2), 159-183. https://doi.org/10.1016/S1061-9518(00)00030-6

Beattie, V., \& Jones, M.J., 2002, 'Measurement distortion of graphs in corporate reports: An experimental study' Accounting, Auditing \& Accountability Journal 15(4), 546-564. https://doi.org/10.1108/09513570210440595

Beattie, V., \& Jones, M.J., 2008a, 'Corporate reporting using graphs: A review and synthesis', Journal of Accounting Literature 27(1), 71-110.

Bernardi, C., \& Stark, A.W., 2016, 'Environmental, social and governance disclosure, integrated reporting, and the accuracy of analyst forecasts', The British Accounting Review 50(1), 16-31. https://doi.org/10.1016/j.bar.2016.10.001

Bray, M., \& Chapman, M., 2012, What does an Integrated Report look like?, viewed 20 September 2018, from https://home.kpmg/content/dam/kpmg/pdf/2013/04/ what-does-ir-look-like.pdf

Brennan, N.M., Guillamón-Saorín, E., \& Pierce, A., 2009, 'Methodological insights: Impression management: Developing and illustrating a scheme of analysis for narrative disclosures-A methodological note. Accounting, Auditing \& Accountability Journal 22(5), 789-832. https://doi.org/10.1108/09513570910966379

Burgess, D., Dilla, W., Steinbart, P., \& Shank, T., 2008, 'Does graph design matter to CPAs and financial statement readers?' Journal of Business \& Economics Research 6(5), 111-124. https://doi.org/10.19030/jber.v6i5.2423 
Chang, L.S., \& Most, K.S., 1985, The perceived usefulness of financial statements for investors' decisions, University Presses of Florida, Florida.

CICA, 1993, Using ratios and graphics in financial reporting: Research report, CICA Toronto.

Clatworthy, M., \& Jones, M.J., 2001, 'The effect of thematic structure on the variability of annual report readability. Accounting, Auditing \& Accountability Journal 14(3), 311-326. https://doi.org/10.1108/09513570110399890

Cleveland, W.S., 1985, The elements of graphing data, Wadsworth Publishing, California.

De Klerk, M., \& Van Wyk, L., 2017, 'Impression management and the use of graphs in integrated reports of the South African mining sector', paper presented at the 2017 Southern African Accounting Association - Biennial International Conference 2017 Southern African Accounting Association - Biennia
Proceedings, Champagne Sports Resort - Drakensberg.

Dudovskiy, J., 2018, Positivism research philosophy, viewed 02 October 2018, from https://research-methodology.net/research-philosophy/positivism/.

Elda, D.T., Renier, V.Z., \& Gina, S., 2017, 'Integrated reporting by South African companies: A case study', Meditari Accountancy Research 25(4), 654-674. https:// doi.org/10.1108/MEDAR-03-2016-0052

Engelbrecht, L., Yasseen, Y., \& Omarjee, I., 2018, 'The role of the internal audit function in integrated reporting: A developing economy perspective', Meditari Accountancy Research 26(4), 657-674. https://doi.org/10.1108/MEDAR-10-2017-0226

EY., 2018, EY's excellence in integrated reporting awards 2018, viewed 27 September 2018, from https://www.bbrief.co.za/content/uploads/2018/08/EY-ExcellenceIn-Integrated-Reporting_2018final.pdf.

Falschlunger, L.M., Eisl, C., Losbichler, H., \& Greil, A.M., 2015, 'Impression management in annual reports of the largest European companies: A longitudinal study on graphical representations', Journal of Applied Accounting Research 16(3), 383-399. https://doi.org/10.1108/JAAR-10-2014-0109

Frownfelter-Lohrke, C., \& Fulkerson, C.L., 2001, 'The incidence and quality of graphics in annual reports: An international comparison', The Journal of Business Communication 38(3), 337-358. https://doi.org/10.1177/002194360103800308

Galpin, J., \& Krommenhoek, R., 2013, Course notes for statistical research design and analysis, School of Statistics and Actuarial Science, University of the Witwatersrand, Johannesburg.

Hallebone, E., \& Priest, J., 2009, Business and management research: Paradigms and practices, Palgrave Macmillan, New York, NY.

Harris, R.L., 2000, Information graphics: A comprehensive illustrated reference, Oxford University Press, Oxford.

Hooks, J., Coy, D., \& Davey, H., 2002, 'The information gap in annual reports', Accounting, Auditing \& Accountability Journal 15(4), 501-522. https://doi. org/10.1108/09513570210440577

IASB, 2018a, Conceptual framework for financial reporting, International Accounting Standards Board, United Kingdom.

IIRC, 2013, The international IR framework, International Integrated Reporting Council, United Kingdom.

IoDSA, 2016, King IV report on corporate governance, IoDSA, South Africa.

IRCofSA, 2014, Preparing an integrated report - A starter's guide, viewed from http:// integratedreportingsa.org/preparing-an-integrated-report-a-starters-guide/.

Jarett, I., 1993, Computer graphics and reporting financial data, John Wiley \& Sons, New York, NY.

Jarett, I., \& Babad, Y., 1988, Financial graphics: Communications for the 1990's: The need for financial graphic standards, Illinois CPA Society, Chicago, IL.

Kosslyn, S.M., 1989, 'Understanding charts and graphs', Applied Cognitive Psychology 3(3), 185-225. https://doi.org/10.1002/acp.2350030302

Leary, M.R., \& Kowalski, R.M., 1990, 'Impression management: A literature review and two-component model', Psychological Bulletin 107(1), 34.

Lee, T.A., 1994, 'The changing form of the corporate annual report', Accounting Historians Journal 21(1), 215-232.

Lee, T.A., \& Tweedie, D.P., 1975a, 'Accounting information: An investigation of private shareholder usage', Accounting and Business Research 5(20), 280-291. https:// doi.org/10.1080/00014788.1975.9728653

Leedy, P.D., \& Ormrod, J.E., 2015, Practical Research - Planning and design, 11 edn., Pearson, Malaysia.

Leivian, G.M., 1980, 'How to communicate financial data more efficiently', Management Accounting (U.S.A) 61(1), 31-34.

Leung, S., Parker, L., \& Courtis, J., 2015, 'Impression management through minima narrative disclosure in annual reports', The British Accounting Review 47(3) 275-289. https://doi.org/10.1016/j.bar.2015.04.002

Marston, C.L., \& Shrives, P.J., 1991, 'The use of disclosure indices in accounting research: A review article', The British Accounting Review 23(3), 195-210. https:// doi.org/10.1016/0890-8389(91)90080-L
Massaro, M., Dumay, J., \& Guthrie, J., 2016, 'On the shoulders of giants: Undertaking a structured literature review in accounting', Accounting, Auditing \& Accountability Journal 29(5), 767-801. https://doi.org/10.1108/AAAJ-01-2015-1939

Mather, D., Mather, P., \& Ramsay, A., 2005, 'An investigation into the measurement of graph distortion in financial reports', Accounting and Business Research 35(2), 147-160. https://doi.org/10.1080/00014788.2005.9729670

Merkl-Davies, D.M., Brennan, N.M., \& McLeay, S.J., 2011, 'Impression management and retrospective sense-making in corporate narratives: A social psychology perspective', Accounting, Auditing \& Accountability Journal 24(3), 315-344. https://doi.org/10.1108/09513571111124036

Neu, D., 1991, 'Trust, impression management and the public accounting profession' Critical Perspectives on Accounting 2(3), 295-313. https://doi.org/10.1016/10452354(91)90015-6

Neu, D., Warsame, H.A., \& Pedwell, K.A., 1998, 'Managing public impressions: Environmental disclosures in annual reports', Accounting, Organizations and Society 23(3), 265-282. https://doi.org/10.1016/S0361-3682(97)00008-1

Pany, K., \& Wheeler, S., 1989, 'Materiality: An inter-industry comparison of the magnitude and stabilities of various quantitative measure', Accounting Horizon $3(4), 71-78$.

Patrick, J., 2009, Research rundowns, viewed 04 October 2018, from https:// researchrundowns.com/.

Penrose, J.M., 2008, 'Annual report graphic use: A review of the literature', Journal of Business Communication 45(2), 158-180. https://doi.org/10.1177/002194360 7313990

Rahman, A.A., Hamdan, M.D., \& Ibrahim, M.A., 2014, 'The use of graphs in Malaysian Companies' corporate reports: A longitudinal study', Procedia - Social and Behavioral Sciences 164(1), 653-666. https://doi.org/10.1016/j.sbspro.2014.11.160

Rentz, K.C., 1992, 'The value of narrative in business writing', Journal of Business and Technical Communication 6(3), 293-315. https://doi.org/10.1177/105065199200 6003002

Reuter, M., \& Messner, M., 2015, 'Lobbying on the integrated reporting framework: An analysis of comment letters to the 2011 discussion paper of the $\| R^{\prime}$ ', Accounting, Auditing \& Accountability Journal 28(3), 365-402. https://doi.org/ 10.1108/AAAJ-03-2013-1289

Rezaee, Z., \& Porter, G.L., 1993, 'Can the annual report be improved?' Review of Business 15(1), 38

Roberts, L., 2014, Special report: Need to get up to speed on integrated reporting viewed 10 October 2018, from https://www.accountancysa.org.za/special-reportneed-to-get-up-to-speed-on-integrated-reporting/.

Rogers, R.K., \& Grant, J., 1997, 'Content analysis of information cited in reports of sellside financial analysts', Journal of Financial Statement Analysis 3(1), 17-30.

Schlenker, B.R., 1980, Impression management: The self-concept, social identity, and interpersonal relations, Brooks/Cole Publishing Company.

Stanga, K.G., 1976, 'Disclosure in published annual reports', Financial Management $5(4), 42-50$

Stanton, P., \& Stanton, J., 2002, 'Corporate annual reports: Research perspectives used', Accounting, Auditing \& Accountability Journal 15(4), 478-500. https://doi. org/10.1108/09513570210440568

Stanton, P., Stanton, J., \& Pires, G., 2004, 'Impressions of an annual report: An experimental study, Corporate Communications: An International Journal 9(1) 57-69. https://doi.org/10.1108/13563280410516500

Steinbart, P.J., 1989, 'The auditors responsibility for the accuracy of graphs in annual reports: Some evidence of the need for additional guidance', Accounting Horizon $3(3), 60-70$.

Surty, M., Yasseen, Y., \& Padia, N., 2018, 'Trends in integrated reporting: A stateowned company analysis', Southern African Business Review 22(1), 1-22. https:// doi.org/10.25159/1998-8125/3841

Taylor, B., \& Anderson, L., 1986, 'Misleading graphs: Guidelines for the accountant', Journal of Accountancy 162(1), 126-135.

Tufte, E., 1983, The visual display of quantitative information, 1st edn., Graphics Press, Cheshire, CT.

Türker, I.-S., \& Zafer, A., 2014, 'The relationship between integrated reporting and financial reporting', Management Studies 2(7), 465-478.

Uyar, A., 2009, 'An analysis of graphic disclosure in annual reports: The case of Turkey', Managerial Auditing Journal 24(5), 423-444. https://doi.org/10.1108/02686900 910956793

Wahyuni, D., 2012, 'The research design maze: Understanding paradigms, cases, methods and methodologies', Journal of applied management accounting research 10(1), 69-80.

Yasseen, Y., Moola-Yasseen, M., \& Padia, N., 2017, 'A preliminary study into impression management practices in chairman's statements in South African annual reports: An attribution theory perspective', Communicare 36(1), 47-66. 